\title{
Pilocytic astrocytoma of sellar/suprasellar region determining endocrine manifestations
}

\author{
Astrocitoma pilocítico da região selar/suprasselar determinando manifestações endócrinas
}

Eduardo Cambruzzi1'; Karla Lais Pêgas² Luciano Carvalho Silveira $^{3}$

\begin{abstract}
Pilocytic astrocytoma (PA) is a grade I glial neoplasm arising mainly in the cerebellum of children. Herein, the authors report a case of PA in a 21 year-old male patient, who presented headache, vomiting and delayed pubertal development. Serum level of cortisol and testosterone corresponded to $32.8 \mathrm{ug} / \mathrm{dl}$ and $0.19 \mathrm{ng} / \mathrm{ml}$, respectively. The computed tomography/magnetic resonance (CT/RM) imaging showed an expansive process compromising suprasellar/hypothalamic region and determining hydrocephalus. The patient underwent resection of the process. Histological evaluation revealed a glial neoplasm constituted by loose glial tissue, small microcysts, areas of dense piloid tissue and Rosenthal fibers. The neoplastic cells were immunoreactive for glial fibrillary acidic protein (GFAP) and negative for chromogranin and synaptophysin. The diagnosis of PA was then established..
\end{abstract}

Key words: pilocytic astrocytoma; central nervous system neoplasms; pathology; brain neoplasms; endocrine diseases.

\section{INTRODUCTION}

Pilocytic astrocytomas (PA) are slowly growing tumors and comprise approximately 5\%-6\% of all gliomas with an overall incidence of 0.37 per 100,000 persons-year ${ }^{(2,5,6,14)}$. The tumor is most common during the first two decades of life without any gender preference. It is the most common brain tumor within the ages of 5 to 19 . In adults, these tumors tend to appear one decade earlier than low grade diffusely infiltrating astrocytomas ${ }^{(2,5,14)}$. The clinical presentation of PA generally consists of a slowly evolving lesion, given their slow growth rate. The tumor may produce focal neurologic deficits or non-localizing signs, including macrocephaly, headache, endocrinopathy, or increased intracranial pressure due to mass effect or ventricular obstruction ${ }^{(2,3,8,14,17)}$.

PA are generally a well-circumscribed, often cystic astrocytoma composed of variable proportions of loose and compact tissue (World Health Organization [WHO] grade I). Having the capacity to form Rosenthal fibers, the hair-like, piloid cells of PA are remarkably similar to reactive astrocytes surrounding various chronic lesions of the hypothalamus, cerebellum and spinal cord. Their histological and cytological resemblance makes such astrocytes prime candidates as precursors $(2,14,16,17)$.
Herein, the authors describe a case of PA in the suprasellar/ hypothalamic location determining hydrocephalus and endocrine disorders. Furthermore, they review pathological and clinical findings of this tumor.

\section{CASE REPORT}

A 21 year-old male Caucasian patient was taken to hospital service referring nausea, headache and vomiting in the last 24 hours. Associated with these symptoms, the patient had decreased pubertal development (height: $1.51 \mathrm{~m}$, weight: $55 \mathrm{~kg}$, no beard, delayed genital development, and thinning of pubic hair), without prior investigation. On physical examination, there were no focal neurological deficits. Ophthalmologic examination demonstrated bilateral edema of the optic nerve papilla. At lumbar puncture, an increase in cerebrospinal fluid (CSF) pressure was observed. The CT/RM imaging showed an expansive process compromising sellar/ suprasellar and hypothalamic regions, which compressed the third ventricle and determined hydrocephalus (Figure 1). The CT/RM imaging of the chest and abdomen showed no changes. At laboratory investigation, serum level of cortisol and testosterone corresponded to

First submission on 16/12/12; last submission on 04/02/13; accepted for publication on 05/02/13; published on 20/04/13

1. Pathologist; post-doctorate in Pathologic Anatomy; professor at Universidade Luterana do Brasil (ULBRA)

2. Pathologist at Santa Casa de Porto Alegre-PR; master's degree in Pathology at Universidade Federal de Ciências da Saúde de Porto Alegre (UFCSPA).

3. Resident in Neurosurgery at Hospital Cristo Redentor, Porto Alegre-PR. 

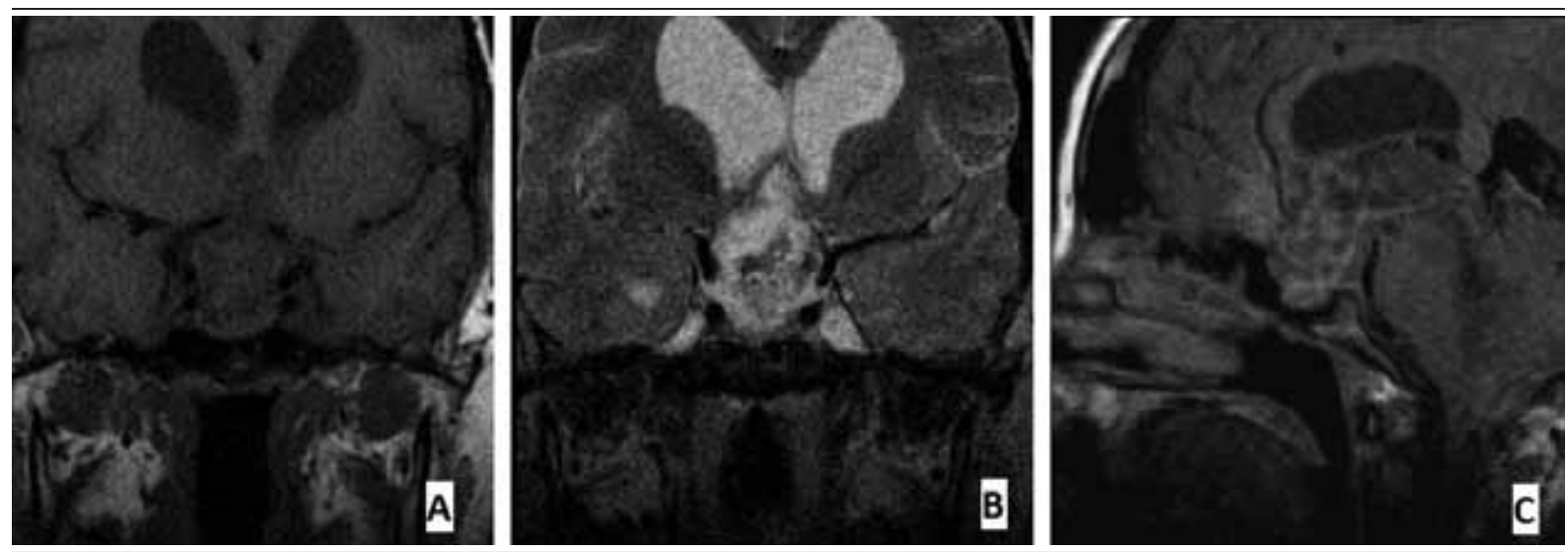

FIGURE 1 - Pilocytic astrocytoma: an expansiveprocess compromising sellar and suprasellar regions, which compressed the thirdventricle and determined hydrocephahus A: coronal T1-weighted image; B: coronal T2-weighted image; C: sagittal postcontrast T1-weighted image.

$32.80 \mathrm{ug} / \mathrm{dl}$ and $0.19 \mathrm{ng} / \mathrm{ml}$, respectively. The relevant laboratory tests are described in the Table. The patient underwent resection of the process and ventriculoperitoneal shunt. On gross examination, the sample comprised some gray, irregular fragments, weighting $1 \mathrm{~g}$, with the largest fragment measuring $0.7 \mathrm{~cm}$. On histological evaluation, a primary central nervous system neoplasm demonstrating a biphasic pattern was evaluated, which was constituted by loose glial tissue (Figure 2) and dense piloid tissue. The loose glial tissue was composed of small microcysts with multipolar cells, round to oval nuclei and short, afibrillar processes. Globular aggregates compatible with eosinophilic granular bodies were identified between astrocytic processes. Some tumor areas consisted of sheets of compact, elongated, bipolar piloid cells, with hair-like processes and Rosenthal fibers (Figure 3). Their nuclei were elongated to oval and bland. There were no significant cytological atypia and areas of necrosis. A low mitotic index was observed. The neoplastic cells were immunoreactive for GFAP (Figure 4), with immunopositivity lower than $01 \%$ for Ki-67 (MIB-1). There was negative immunoexpression for cytokeratin, chromogranin and synaptophysin. The diagnosis of PA was then established.

TABLE - Pilocytic astrocytoma: clinical data

\begin{tabular}{ccc}
\hline & Serum value & Normal serum \\
\hline T3 & $49 \mathrm{ng} / \mathrm{dl}$ & $80-200 \mathrm{ng} / \mathrm{dl}$ \\
Free T4 & $0.90 \mathrm{ng} / \mathrm{dl}$ & $0.93-1.70 \mathrm{ng} / \mathrm{dl}$ \\
T4 & $5.8 \mathrm{ng} / \mathrm{dl}$ & $5.1-14.1 \mathrm{ng} / \mathrm{dl}$ \\
Testosterone & $0.19 \mathrm{ng} / \mathrm{ml}$ & $2.8-8 \mathrm{ng} / \mathrm{ml}$ \\
Prolactin & $79.1 \mathrm{ng} / \mathrm{ml}$ & $4.1-18.4 \mathrm{ng} / \mathrm{ml}$ \\
Progesterone & $0.56 \mathrm{ng} / \mathrm{ml}$ & $0.2-1.4 \mathrm{ng} / \mathrm{ml}$ \\
TSH & $1.03 \mathrm{mUI} / \mathrm{ml}$ & $0.27-4.20 \mathrm{mUI} / \mathrm{ml}$ \\
LH & $0.1 \mathrm{mUI} / \mathrm{ml}$ & $1.7-8.6 \mathrm{mUI} / \mathrm{ml}$ \\
FSH & $1.9 \mathrm{mUI} / \mathrm{ml}$ & $1.5-12.4 \mathrm{mUI} / \mathrm{ml}$ \\
Cortisol & $32.80 \mathrm{ug} / \mathrm{dl}$ & $6.2-25 \mathrm{ug} / \mathrm{dl}$ \\
\hline
\end{tabular}

T3: triiodothyronine; T4: thyroxine; TSH: thyroid-stimulating hormone; LH: luteinizing hormone; FSH: follicle stimulating bormone.

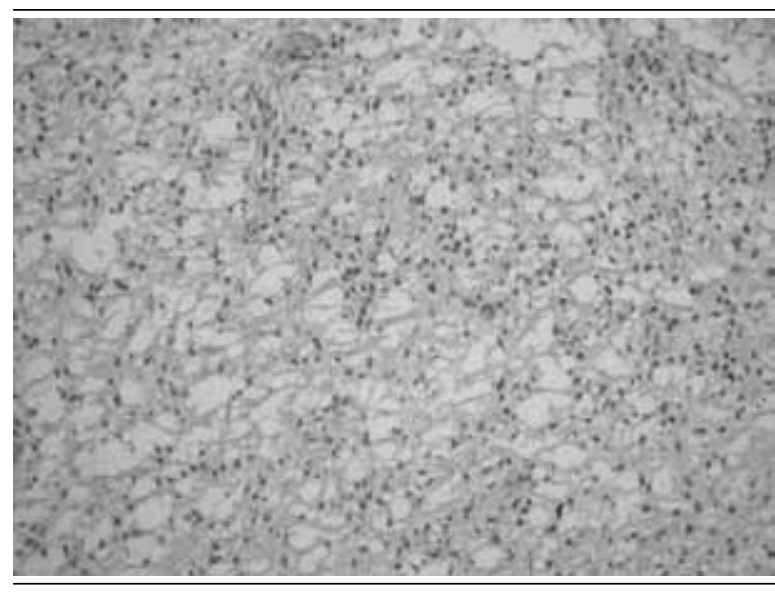

FIGURE 2 - Pilocytic astrocytoma exbibiting spongy, microcystic area. HE, 100× HE: hematoxylin and eosin.

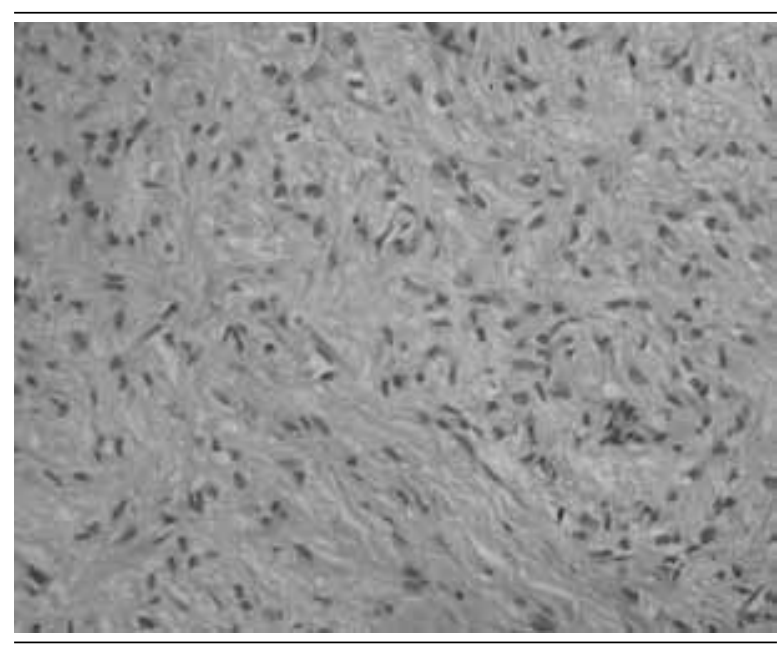

FIGURE 3 - Pilocytic astrocytoma exbibiting occasional Rosenthal fibers. HE, 200×

HE: hematoxylin and eosin. 


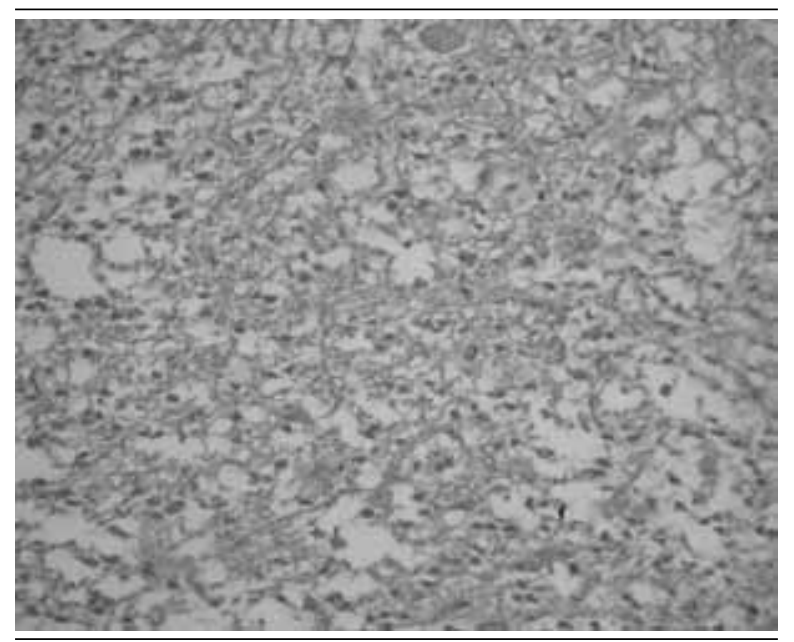

FIGURE 4 - Pilocytic astrocytoma showing positive immunoexpression for GFAP, streptavidin-biotin, 200×

GFAP: glial fibrillary acidic protein.

\section{DISCUSSION}

PA arising in the hypothalamus corresponds to approximately $11 \%$ of cases of this neoplasm. Hypothalamic/pituitary dysfunction, including obesity and diabetes insipidus, is often but not invariably apparent in large hypothalamic examples ${ }^{(1-3,14)}$. PA arising in sellar and suprasellar regions may determine changes in the release and/or production of hormones, inasmuch as the compressive or even invasive effect of the neoplasm may affect the physiology of the hypothalamus or pituitary gland. Lizarraga et al. describe only two cases of hormonal disturbances related to PA in a series of twelve patients ${ }^{(7)}$. Majchrzak et al. describe two cases of diabetes insipidus associated with hypothalamic neoplasms ${ }^{(8)}$. Scheithauer et al. relate that PA occasionally determines hypothalamic dysfunction, which may result in sexual precocity, obesity and diabetes insipidus ${ }^{(14)}$.

Since any given hypothalamic hormone is commonly produced in more than one nucleus, and, in many cases, a single nucleus may express several hormones, different clinical signs may be found in this group of patients. Structure-function correlations are complex because of the functional heterogeneity of many hypothalamic nuclei. Alterations in the suprachiasmatic nucleus of the hypothalamus may be associated with decrease in gonadotropin release. Lesions of the supraoptic nuclei may decrease the synthesis of oxytocin and vasopressin. Destruction of the ventromedial nucleus results in obesity; conversely, destruction of the ventrolateral nucleus causes anorexia and cachexia. The arcuate (infundibular) nucleus plays a major role in the modulation of anterior pituitary function. The paired medial and lateral nuclei are linked with autonomic function, particularly temperature control and olfaction. The posterior nucleus has been implicated in temperature regulation and its large neurons are thought to be the source of hypothalamic efferents, which descend to the reticular formation of the brainstem ${ }^{(1,11)}$.
The consequences of hypothalamic tumors result from lesions of the hypothalamic nuclei, pituitary dysfunction, and impairment of adjacent nervous structures. Functional changes determined by PA arising in the hypothalamus include syndromes of hyperfunction or hypofunction. The hyperfunction syndromes include early puberty, ectopic production of hypothalamic hormones, and inappropriate secretion of antidiuretic hormone. The hypofunction syndromes may determine hypothalamic dwarfism, the so called diencephalic syndrome, obesity, hypothalamic hypogonadism, amenorrhea, diabetes insipidus and hypopituitarism. Other functional disorders include changes in appetite and thirst, hypothermia, hyperthermia disorders in the pattern of sleep and wakefulness, behavioral disorders, visual disturbances, spasticity, hyperreflexia, ataxia and uncoordinated movements ${ }^{(1,2,9,11)}$.

In the present case, the authors describe a PA originated in the hypothalamus that determined hypofunction syndrome (hypogonadism). Thus, damage in the nuclei that regulate the secretion of luteinizing hormone (LH) and follicle stimulating hormone (FSH) (serum levels: $0.1 \mathrm{mUI} / \mathrm{ml}$ and $1.9 \mathrm{mUI} / \mathrm{ml}$, respectively) caused testosterone deficiency (serum level: $0.19 \mathrm{ng} / \mathrm{ml}$ ). Clinically, this deficiency determined the alterations related to the secondary sexual characteristics (no beard, delayed genital development, and thinning of pubic hair). The increase in prolactin serum levels $(79.1 \mathrm{ng} / \mathrm{ml})$ may be attributed to damage in the arcuate nucleus, which controls the secretion of dopamine (an inhibitor of prolactin secretion). Hypothalamic hypogonadism (HH) occurs by decreased secretion of gonadotropin-releasing hormone $(\mathrm{GnRH})$ or non-pulsatile secretion of this hormone, which may result in lack of sexual maturation, or pituitary hormone deficiency due to hypothalamic dysfunction. In post-pubertal males, symptoms related to $\mathrm{HH}$ may include impotence and reduction in libido. Patients with secondary hypogonadism (hypothalamic) have low serum levels of testosterone and low to normal serum levels of LH and FSH. Patients with primary hypogonadism (testicular) have low serum levels of testosterone and high levels of $\mathrm{LH}$ and FSH. In severe cases of $\mathrm{HH}$, the basal levels of estradiol and serum gonadotropin response to $\mathrm{GnRH}$ are reduced, which indicate a defect in the tonic and cyclic secretion of GnRH. The isolated GnRH deficiency characterizes Kallmann syndrome. Hyperprolactinemia in some cases of hypothalamic PA exerts an inhibitory activity on the positive feedback effect of estradiol on GnRH secretion ${ }^{(10-12,15)}$. The increase in prolactin in cases of PA seems to depend on the decrease in factors that inhibit prolactin secretion, namely dopamine produced by the arcuate nucleus of the hypothalamus, which is probably damaged by $\mathrm{PA}^{(4)}$. In males, hyperprolactinemia causes hypogonadism, and may be manifested as reduction in libido and impotence, occasionally followed by gynecomastia. In females, hyperprolactinemia may determine galactorrhea, oligomenorrhea/amenorrhea and infertility. In hypothalamic dwarfism, patients have more often thyrotroph and growth hormone deficiency, which determine a shorter height owing to premature fusion of the epiphyseal cartilage. These patients have normal proportions between the limbs, trunk, abdomen, and head. The presence of hypopituitarism associated with hypothalamic PA may be accountable for the compressive effect of the neoplasm ${ }^{(4,10-13,15,18,19)}$. 
Herein, the authors presented a case of PA related to an uncommon clinical presentation: a male adult patient exhibiting delayed pubertal development and endocrine disorders due to a PA affecting the suprasellar/hypothalamic location. An excellent follow-up is expected in the present case, although a risk for recurrence has been described in the literature in cases of hypothalamic PA.

\section{RESUMO}

O astrocitoma pilocítico (AP) é uma neoplasia glial grau I encontrada principalmente no cerebelo de crianças. Os autores relatam um caso de AP em paciente masculino, 21 anos de idade, que apresenta cefaleia, vômitos e retardo do desenvolvimento puberal. Os níveis séricos de cortisol e testesterona corresponderam a 32,8 ug/dl e 0,19 ng/ml. A tomografia computadorizada/ressonância magnética (TC/RM) identificaram um processo expansivo que comprometia a região suprasselar/hipotalâmica e determinava bidrocefalia.Opaciente foi submetido à ressecção do processo. À microscopia, foi identificada uma neoplasia glial constituída por tecido glial frouxo, pequenos microcistos, áreas de tecido piloide denso e fibras de Rosenthal. As células neoplásicas foram imunopositivas para glial fibrillary acidic protein (GFAP) e negativas para cromogranina e sinaptofisina. O diagnóstico de AP foi, então, estabelecido.

Unitermos: astrocitoma pilocítico; neoplasias do sistema nervoso central; patologia; neoplasias encefálicas; doenças do sistema endócrino.

\section{REFERENCES}

1. ASA, S. L. Hypothalamus and neurohypophysis. In: ASA, S. L. AFIP atlas of tumor pathology, tumors of the pituitary gland, Series 4, Washington: ARP, 2011 , v. 15 , p. 10-2.

2. BURGER P. C.; SCHEITHAUER B. W. Pilocytic astrocytoma. In: BURGER P. C.; SCHEITHAUER B. W. AFIP atlas of tumor pathology, tumors of the central nervous system, Series 4, Washington: ARP, 2007, v. 7, p. 89-106.

3. CHOI, K. H. et al. Astrocytoma in the third ventricle and hypothalamus presenting with parkinsonism.J Korean Neurosurg Soc, v. 51, n. 3, p. 144-6, 2012.

4. HORVATH, E. V. A.; SCHEITHAUER, B. W.; KOVACS, K.; LLOYD, R. V. Hypothalamus and pituitary. In: GRAHAM, D. I.; LANTOS, P. L. Greenfield's neuropathology. 7. ed. London: Arnold, 2002, v. 2, p. 983-1062.

5. KLEIN, 0. et al. Childhood diencephalic pilocytic astrocytoma. A review of seven observations. Neurochirurgie, v. 52, n. 1, p. 3-14, 2006.

6. KURKHARD, C. et al. A population-based study of the incidence and survival rates in patients with pilocytic astrocytoma. J Neurosurg, v. 98, n. 6, p. 1170-4, 2003

7. LIZARRAGA, K. J. et al. Stereotactic radiation therapy for progressive residual pilocytic astrocytomas. J Neurooncol, v. 109, n. 1, p. 129-135, 2012.

8. MAJCHRZAK, K. et al. Rare primary tumours of the hypothalamus in adults: clinical course and surgical treatment. Neurol Neurochir Pol, v. 44, n. 6 , p. 546-53, 2010.

9. MORENO VILLARES, J. M. et al. Diencephalic syndrome: an uncommon cause of malnutrition. An Esp Pediatr, v. 56, n. 5, p. 466-71, 2002.
10. NARAYANAN, R. P. et al. Hypogonadism secondary to hyperprolactinaemia: successful treatment bur adverse consequences. Exp Clin Endocrinol Diabetes, v. 120, n. 5, p. 311-3, 2012.

11. PITTELLA, J. E. H. et al. Hipotálamo. In: GERALDO, B. F. Bogliolo patologia. 8. ed. Rio de Janeiro: Guanabara Koogan, 2011, p. 1103-9.

12. RABIJEWSKI, M.; ZGLICZYNSKI, W. Pathogenesis, evaluation and treatment of hypogonadism in men. Endokrynol Pol, v. 60, n. 3, p. 222-33, 2009.

13. REIS, A. et al. Pilocytic astrocytoma of neurohypophysis. Neuropathology, v. 23, n. 3, p. 214-18, 2003.

14. SCHEITHAUER B. W. et al. Pilocytic astrocytoma. In: LOUIS, D. N.; OHGAKI, H.; WIESTLER, 0. D.; CAVENEE, W. K. WHO classification of tumours of the central nervous system - pathology \& genetics. Lyon: IARC Press, 2007, p. 14-20.

15. TAYLOR, M. et al. Hypothalamic-pituitary lesions in pediatric patients: endocrine symptoms often precede neuro-ophtalmic presenting symptoms. J Pediatr, v. 161, n. 5, p. 855-63, 2012.

16. TCHOGHANDJIAN, A. et al. Pilocytic astrocytoma of the optic pathway: a tumour deriving from radial glia cells with a specific gene signature. Brain, v. 132, n. 6, p. 1523-35, 2009.

17. TIHAN, T. et al. Pathologic characteristics of pediatric intracranial pilocytic astrocytomas and their impact on outcome in 3 countries: a multiinstitutional study. Am J Surg Pathol, v. 36, n. 1, p. 43-55, 2012.

18. TSIGKAROPOULOU, E. et al. Hypogonadism due to hyperprolactinemia and subsequent first episode of psychosis. Gend Med, v. 9, n. 1, p. 56-60, 2012.

19. VISWANATHAN, V.; EUGSTER, E. A. Etiology and treatment of hypogonadism in adolescents. Pediatr Clin North Am, v. 58, n. 5, p. 1181200, 2011

\section{MAILING ADDRESS}

Eduardo Cambruzzi

Hospital Conceição de Porto Alegre; Av. Francisco Trein, 596, 2º andar; Laboratório de Patologia; Cristo Redentor; CEP: 91350-200; Porto Alegre-RS, Brazil; Tel.: (51) 3357-2164; e-mail: dudacambruzzi@yahoo.com.br. 